\section{artelogie}

\section{Artelogie}

Recherche sur les arts, le patrimoine et la littérature de l'Amérique latine

$14 \mid 2019$

Sensibilités : Arts, littératures et patrimoine en

Amérique latine

\title{
Representaciones de la experiencia parisina. ¡No contaban con mi astucia! - Sobre héroes, demonios y narcóticos en América Latina
}

\section{Carlos Velázquez}

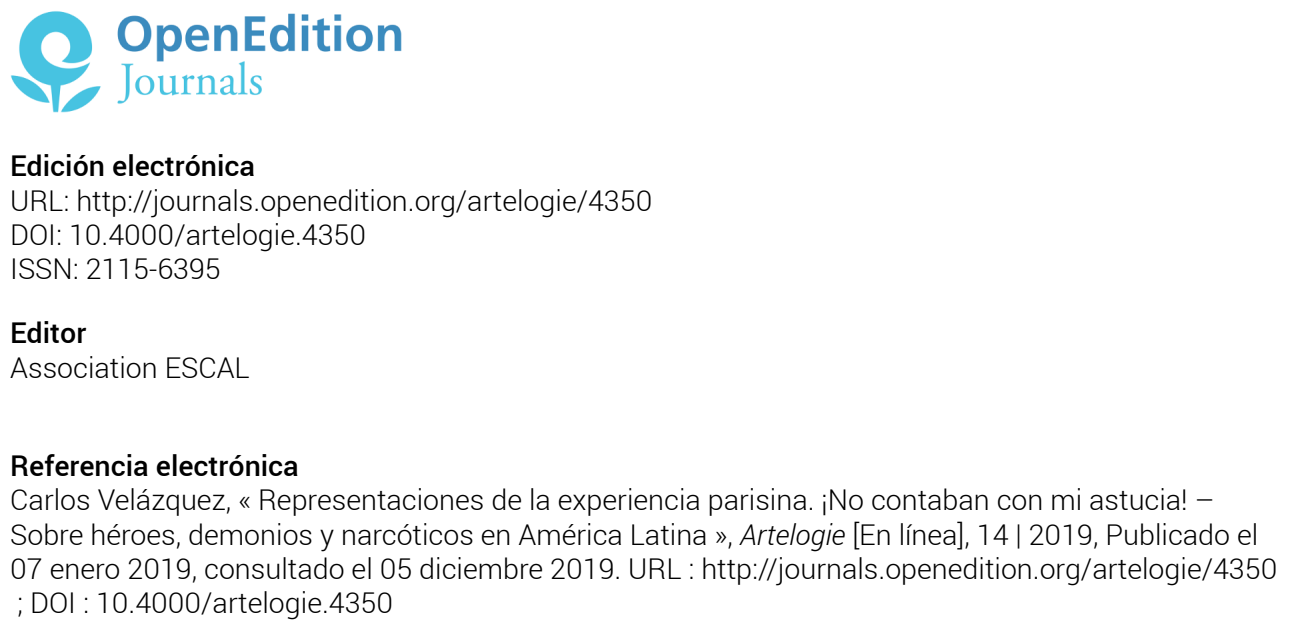

Este documento fue generado automáticamente el 5 diciembre 2019.

Association ESCAL 


\title{
Representaciones de la experiencia parisina. ¡No contaban con mi astucia! - Sobre héroes, demonios y narcóticos en América Latina
}

\author{
Carlos Velázquez
}

\section{Preámbulo demonológico}

1 Un Chulachaqui. Es eso lo que vaga a la deriva sobre las aguas rasas de la riqueza especulativa. Y lo peor es que vaga creyendo que está en el control. Chulachaqui. Así le llaman los indígenas de la selva amazónica a un espíritu que se perdió de su alma, como explica el sabio Karamakate del pueblo Cohiuano1: "Todos tenemos un chulachaqui. Se parece con nosotros, pero está vacío, hueco. Es solo el recuerdo de un tiempo que pasó. Un chulachaqui no tiene memoria. Vaga por el mundo, vacío, como un fantasma, perdido en un tiempo sin tiempo." (GUERRA, 2015) Se trata de lo que Jung también observó entre los llamados hombres primitivos: la pavorosa pérdida del alma, lo que, en términos más técnicos - como él mismo dijo - conoceríamos hoy como disociación de la consciencia (JUNG, 1964: p.24).

2 Es que por estas tierras, como en tantas otras, el proyecto moderno de mundialización o tal vez apenas de economía global - aconteció como es debido, para tomar la expresión de Morin. Es decir, "se desarrolló en y por la violencia, destrucción, esclavatura, explotación feroz" (MORIN; CIURANA; MOTTA, 2003: p.69) y como aún vivimos bajo esos preceptos y estamos demasiado preocupados con la sobrevivencia, creo que no hemos dado la debida atención a otro tipo de violencia que, por pasar desavisada, el chulachaqui aprovecha para poseernos. Se trata de la violencia del choque entre sueños, como lo observó Le Clézio en México y como sucedió con los otros pueblos bárbaros que también fueron violados por el imperialismo occidental. "De un lado, el mundo individualista y posesivo de Hernán Cortés; mundo de cazador, ladrón de oro, que mata 
los hombres y conquista las mujeres y las tierras. Del otro, el mundo colectivo y mágico de los indios, cultores de maíz y de frijol, campesinos sumisos a un clero y a una milicia, adoradores del Rey Sol que representa sus dioses sobre la tierra." (LE CLÉZIO, 1988: p.21)

3 Como es debido, dice Morin, y estoy de acuerdo con él; no hay transformación sin violencia, por eso la guerra. Solo que, mientras la guerra de los primitivos era ritual, de antemano definida para experimentar los acuerdos misteriosos entre potencias celestes; la guerra civilizada procura la pose y la ganancia, a despecho del apaciguamiento de los dioses que se alimentarían del corazón y de la sangre de vencidos y vencedores. ¿Cómo ganar la guerra? ¿Cómo, si eran hombres "que integraban un todo, una única y misma alma dominada por sus dioses, [...] frente al hombre individualista y escéptico del mundo moderno?" (LE CLÉZIO, 1988: pp.20-21)

4 Nos lo había advertido también Lévy-Bruhl (2002: p.37), lo visible y lo invisible, en la mentalidad primitiva, son inseparables. De hecho, lo invisible es mucho más presente, activo y temible, por lo que ocupa el alma de forma determinante y evita que el espíritu se profundice en el tipo de reflexión que conocemos como objetiva. ¿De qué serviría, si la felicidad, la salud, el orden natural, en fin, todo, a cada instante, depende de los poderes místicos? El esfuerzo humano no debe malgastarse en tentativas de reglamentar su ambiente; es mejor interpretarlo para integrarse a él. Así que, como pensaba Le Clézio, "a pesar de los sacrificios sangrientos, de la antropofagia ritual, de su tiranía teocrática, no hay duda de que los Aztecas - como los Mayas o los Tarascos - [en ese enfrentamiento] eran la parte civilizada" (LE CLÉZIO, 1988: p.41) o, por lo menos, diría yo, habían construido una civilización digna de ponderación análoga a la del invasor.

De todos modos, eso no impidió que el chulachaqui Vespucio estimara justo que este vasto territorio - el nuevo mundo - portara su nombre, América, y substituyera sus escrituras jeroglíficas por los sistemas fonéticos de las lenguas derivadas del latín.

Hay que reconocer, sin embargo, que no todo era a favor de los latinos europeos. La disociación neurótica que venía preparándose en el viejo continente hacía gala de su odio al cuerpo (LE BRETON, 2013) procurando substituir la fuerza de trabajo por la fuerza de las máquinas y, en esa neurosis, los anglosajones lideraban. Más una vez apelo a la lúcida sensibilidad de Le Clézio, al observar que "al mundo fantástico, mágico y cruel de los Aztecas, Mayas y Purépechas, seguirá lo que llamamos civilización: esclavitud, oro, explotación de tierras y hombres, todo lo que anuncia la era industrial." (LE CLÉZIO, 1988: p. 59) De esta forma, el chulachaqui garantizó un triunfo de proporciones continentales. Los anglosajones vinieron, se apropiaron de los recursos e hicieron de la América Latina su América ideal, libre de latín. Es cierto que, geográficamente, aún somos dos Américas, América y América Latina; pero es que justamente es ese el hechizo de nuestro demonio: El espíritu desconoce el alma, cree haberse librado de ella, aunque el alma no desaparece, se torna invisible $\mathrm{y}$, si bien recordamos, lo invisible es más presente, activo y temible.

7 En Perú, por ejemplo, la gente tiene miedo de que, alejados de la seguridad que brindan las dependencias urbanas de la civilización, les aparezca el chulachaqui. Un ser antropomorfo, pero mínimo y deformado, con un pie humano y otro animal y que engaña a las personas para que se pierdan en la selva (ARGUEDAS; RÍOS, 2009: pp. 127-129). Pero lo que las personas han visto no es el demonio propiamente. Los seres fantásticos no tienen forma. Lo que ven es la forma que le atribuyen a una parte de ellos mismos y que no es tomada en cuenta por su consciencia. Veamos: el chulachaqui es antropomorfo porque es parte de una persona, pero mínimo y deformado porque 
aquella parte del ser fue marginalizada por la personalidad consciente; tiene un pie humano porque hace parte de lo humano, pero el otro es animal porque asume la naturaleza animal que el hombre civilizado niega. Ya que lo han excluido del complejo cultural, amenaza secuestrar los habitantes urbanos para entregarlos, de nuevo y para siempre, a la naturaleza, donde se perderán. Dicho de otra forma, lo que la consciencia rechaza es relegado al inconsciente, pero no se pierde; desde allá es proyectado sobre otros objetos, circunstancias o delirios y acaba que las personas, o los grupos sociales, ven en lo ajeno lo que desconocen en sí. La psicología analítica conoce este fenómeno como proyección (JUNG, 2013: pp.66-71). Con esta noción podemos comprender que, perceptivamente, la América anglosajona - como lo dije - es América y que la parte que se niega por ser mínima, sucia y deformada, dominada por la animalidad de los instintos y que amenaza tragar y extraviar para siempre a quien tenga la osadía de aproximarse, es el dominio del chulachaqui; el alma disociada; el inconsciente latino del continente americano.

8 Lógicamente, en la realidad cívica, las personas y los países del continente americano tienen sus propias fragmentaciones y oposiciones internas; sin embargo, en beneficio de la perspectiva continental que pretendo desenvolver y en alusión a la clara autoreferencialidad anglosajona, reiterada por una parte significativa de la América Latina, suspenderé particularidades para metaforizar la cultura americana como centro egóico de la consciencia y América Latina como su contraparte inconsciente.

\section{La escisión}

San Agustín de Hipona, empero europeo, era un sabio preocupado con la disociación entre alma y espíritu. Decía él que el cuerpo es dado a las pasiones y, como el alma habita el cuerpo, al alma le interesan las pasiones también. Pero si el espíritu es unilateralmente focalizado en el deleite pasional puede acabar aprisionando el alma en el cuerpo y, de esa forma, extraviando su propio sentido, dado que el alma aprisionada no estaría más en condiciones de articularse con lo transcendental, lo invisible o, en su decir, con Dios. El ser quedaría pues a la deriva, a merced de un espíritu vacío y sufriría, en consecuencia, enfermedades provocadas por los incomodos del alma confinada a tan limitado espacio. Una posible solución sería ofrecer al espíritu estímulos perceptivos capaces de resonar en el alma e incitarla, por lo tanto, a renovar sus articulaciones con lo divino. (SAN AGUSTÍN, 2008: pp. 364-381) No es un acaso que estos pensamientos se encuentren en el tratado de música del presbítero de Hipona, evidentemente, ciertas estructuras musicales serían ideales para hacer resonar el alma; pero volveré a este aspecto un poco adelante. Por el momento, interesa percibir que, frente a una situación de disociación de la consciencia, como la descrita, el alma activa reacciones autoreguladoras, a ejemplo de las enfermedades que asolan al ser disociado.

10 En los albores del siglo XX, C. G. Jung ponderó abiertamente ese carácter autoregulador de la psique, acrecentando que de los incomodos del alma confinada provienen materiales inconscientes, constelados en símbolos y temas míticos que precisan ser interpretados para que la consciencia los asimile (JUNG, 2009: pp. 398-400), es decir, para que el espíritu (consciencia) y el alma renueven su articulación unificadora. Es por eso que los mitos y sistemas simbólicos que el psiquiatra destaca se encuentran a la base de cualquier religión (ELIADE, 2001), pues su función es re-ligar las partes disociadas (CAMPBELL, 2008: p.31). Es, entretanto, necesario tener cautela con la 
interpretación de símbolos y mitos que Jung preconiza, pues se trata de un movimiento adaptativo e integrativo, en los moldes descritos por Lévy-Bruhl, antes que de una apropiación meramente intelectual. Como dijo Eliade, una experiencia verdaderamente religiosa implica vivir los mitos (1972: p.18). En todo caso, de esta perspectiva podemos destacar que la religión y sus mitos vividos, o sea, sus ritos (ELIADE, 1992), son excelentes vías para la re-articulación de espíritu y alma. Aunque permanece la cuestión de la música de San Agustín. De hecho, el sabio cohiuano Karamakate recomendaba a los niños indígenas lo siguiente: "Nunca olviden quienes son y de donde vinieron. No permitan que su música desaparezca." (GUERRA, 2015)

11 Una solución fácil sería declarar que el Arte, la Religión y los Ritos constituyen el trípode de la articulación espíritu y alma, sobre todo cuando sabemos que esas tres actividades humanas, en sociedades mágicas como las que habitaban el continente precolombino, no eran distintas entre sí. Xochicuicatl, flor-y-canto, la verdad hecha poesía, era el lenguaje de los Tlamatinime de las culturas nahuatl, hombres sabios, ejemplares, temerosos de los dioses y líderes en pruebas y sacrificios rituales (LEÓNPORTILLA, 2001: p.320). Poesía y canto son artes, claro, pero ¿nos referimos a lo mismo cuando hablamos de arte en la actualidad? Para San Agustín, la música es la "ciencia del mover bien, de manera que el movimiento sea apetecido por sí mismo y por ello deleite por sí mismo" (SAN AGUSTÍN, 2008: p.95) y no podría ser diferente, ya que el nombre le viene de la omnipotencia que suele concederse a las Musas sobre el cantar (SAN AGUSTÍN, 2008: p.89). Según Platón, la música implica un "comercio inteligente con las musas" (2002: p.110), como lo confirma Gómez de Silva al definir la música como "cualquier arte protegido por las musas" (1998: p.474). Y es que, el recurso a las musas no es una licencia poética, sino una concepción mítica. Hijas de Mnemosine, la memoria arcaica, las musas eran regidas por Apolo, la consciencia expansiva, oracular, la cual, a través de las artes musicales, procura comunicación articulada con la memoria fantasmal, arquetípica. (VELÁZQUEZ, 2015: pp.83-ss) Dicho de otra forma, las musas procuran comunicación con el nunca-olviden-quienes-son-y-de-donde-vinieron de los cohiuanos, o con las resonancias del alma de San Agustín. Hay aquí un evidente movimiento espiritual; pero el movimiento ponderado por San Agustín es literal e integral. Las nueve musas fueron criadas para alabar la gloria del Olimpo (BRANDÃO, 2014: p.438), lo que realizan básicamente cantando y danzando (KURY, 2009). Si tenemos en cuenta que el canto exige una letra, tendremos que las artes de las musas implican la retórica, la música y la danza, orquestando el movimiento corporal con la vibración material en el ambiente y el dislocamiento espiritual, a partir del lenguaje (cultura), a procura de sus raíces mnemónicas. Es, sin duda, sobre esta base que Plotino afirmó que la retórica, la música y la danza son las artes que modifican a los hombres, tornándolos mejores o peores (PLOTINO, 2012). La misma noción es cristalina en la voz de los indígenas chibcha de la Sierra Nevada de Santa Marta: la danza nos une a las fuerzas divinas porque tiene la memoria de dónde venimos y la espiritualidad de la cultura (GUTIÉRREZ; TORRES, 2016). En fin, pretendo mostrar que el arte, en la concepción de los pueblos mágicos, procuraba transcender la precariedad espiritual, implicando la participación del ser total. Una verdadera participación mística en los moldes que Jung atribuía a Lévy-Bruhl (JUNG, 1964: p.24). Noción que prevaleció en Europa hasta el final de la Edad Media y que Subirachs designa como, "las artes que se desarrollan prioritariamente en el tiempo" (1995: p.09); artes del movimiento, en oposición a las artes de la forma y del color que la Historia del Arte tradicionalmente acepta, como advierte Xavier Barral (1990: p.10-11). 
12 El caso es que la concepción de arte que los colonizadores renacentistas impusieron en el Nuevo Mundo fue la segunda, la de la Historia del Arte. Según Francastel, en torno del siglo XV, el arte europeo, por un proceso semejante al de la formación de la consciencia descrito por Piaget, abandonó su carácter mítico, mágicamente significante, por una visualidad cientificista que aún profundiza un distanciamiento psíquico entre el hombre y la naturaleza (FRANCASTEL, 1990). En palabras de Lévi-Strauss, el arte “ perdió el contacto con su función significativa en la escultura griega y tornó a perderlo en la pintura italiana del Renacimiento. [...] tomó durante mucho tiempo un carácter cada vez más representativo y cada vez menos significativo." (CHARBONNIER, 1989: p.57-63) El espaciotiempo, antes dimensión del mover bien de San Agustín, fue reducido por las molduras de los cuadros a momentos aislados, a la instantaneidad que la fotografía más tarde consumón ${ }^{1}$.

13 Son innegables los beneficios que las artes plásticas y visuales pueden ofrecer en materia de rearticulación espíritu y alma; basta conocer, por ejemplo, la inestimable labor de Nise da Silveira contra los procedimientos manicomiales en Brasil. Entretanto, como ella misma declaró, la pintura de los internos en el Engenho de Dentro tornó visibles inúmeras condiciones vividas subjetivamente (MUSEU DE IMAGENS DO INCONSCIENTE, 1987: p.5), lo que significa que incentivar a los pacientes a pintar fue un recurso terapéutico eficaz en la colecta de materiales anímicos particulares, pasibles de significación, o sea, pasibles de rearticulación cultural. De acuerdo con Lévi-Strauss, "la pintura organiza intelectualmente, por medio de la cultura, una naturaleza que ya estaba frente a ella como organización sensible. La música realiza un trayecto exactamente inverso, pues es la cultura la que estaba frente a ella, solo que de forma sensible." (2010: p.42) Y es precisamente ese movimiento de salir para colectar, para tomar posesión de algo, el que, con relativa facilidad, puede cobrar dimensiones poco deseables. Poseer una imagen en lugar de entregarse a una experiencia, a la participación-del-ser-total, fue el motivo de la desconfianza de Platón en relación a la pintura (2000: p.324); análogamente, en el marco del arte moderno, es esa la motivación de Lévi-Strauss al declarar que "es en esa exigencia ávida, en esa ambición de capturar el objeto en beneficio del propietario o incluso del espectador, donde parece residir una de las grandes originalidades del arte de nuestra civilización." (CHARBONNIER, 1989: p.58) Declaración que talvez corresponda a la necesidad occidental, observada por Jung, de reducir la vida a imágenes y conceptos, aun cuando el precio sea apartar-se de sus misterios. (JUNG, 1971: p.66)

De todas formas, lo que en la historia del arte es una evolución, en materia anímica configura un proceso de disociación: el arte de la crisis vanguardista en Europa, asolado por las guerras mundiales, fue transportado para América (GUILBAUT, 2007) - para la parte sin latín - donde, para ser aceptable, Clement Greenberg lo hizo propio y exclusivo de las clases adineradas (1997) y Arthur Danto lo emancipó de lo sensible para consagrarlo como pura teoría $(2000,2006)$. Hoy, para ser sinceros, nadie sabe muy bien lo que es arte y pocos se atreven a reconocerlo, a ejemplo del eminente historiador del arte Ernst Gombrich quien, de forma un tanto juguetona, reconoce que el arte con $\mathrm{A}$ mayúscula no existe ${ }^{2}$.

15 El arte actual es volátil, se presenta en estado gaseoso como lo dice Michaud (2007). El campo del arte es blanco de múltiples inserciones sociales, políticas, económicas y mediáticas que lo sobrepasan, lo rasgan y lo desfiguran; haciendo que los circuitos cerrados - ególatras y posesivos - que en un pasado reciente legitimaban a los que podían decir lo que era arte también se desvanezcan (CANCLINI, 2012: pp.29-38). Como 
dije, resta un chulachaqui. Y creo que nadie ha captado ese espíritu maligno como lo hizo García Canclini al observar el comportamiento de los actuales "peregrinos del turismo cultural: [...] en Europa, primero Paris; en Paris el Louvre; dentro del Louvre, la Venus de Milo y la Gioconda, [pero] si no tengo tiempo de ver la Venus de Milo, tengo que ver al menos la Gioconda, porque he leído El código Da Vinci." (CANCLINI, 2013: p.10)

El problema no es el patrimonio artístico. El problema es que la pérdida de la función transcendente en el arte enterró con ella la propia noción de transcendencia. Transcender la precariedad del espíritu humano para articularse con el alma era el verdadero tesoro del mítico $\mathrm{El}$ Dorado; pero fue también la riqueza perdida en el violento choque entre sueños que despertó América. Sin ideal de transcendencia, la humanidad se encierra en una inmovilidad moral que suspende todo lo vivo. Todo riesgo, desgaste o sufrimiento es negado, renegado sobre la imagen de un mesías que sufrió en nuestro lugar, a despecho de un modelo heroico que, internamente, somos compelidos a imitar. Por eso formulamos el pecado; no importa si nuestros actos son graves o incongruentes, pues la penitencia para librarnos de la culpa no es tan inalcanzable. En tales circunstancias, el hombre religioso se ve obligado a acompañar apenas en parte la imagen del redentor o a optar por no acompañarla de ninguna manera. A su vez, la iglesia, atenta a la debilidad inherente a la especie humana, se siente obligada a flexibilizar su rigor doctrinario, reforzando así una relativización moral que debilita y desgasta sus símbolos básicos y, con ellos, su propia autoridad (JUNG, 2011: pp.33-34).

Sin arte y sin religión el chulachaqui piensa que ganó, solo que, recuerde, el alma queda presa en el cuerpo y por más que ese espíritu, que se cree emancipado, niegue, desdeñe, insulte y agreda, inevitablemente habita el mismo cuerpo. Es ese el dilema que nos revela la antropología del cuerpo de Breton. El sueño de una humanidad libre del cuerpo es lógica en el ambiente excesivamente tecnificado, devoto de la mediación y la simulación, en el que transcurre la vida diaria. El sueño - o el proyecto - de transferir el espíritu a un computador para vivir plenamente el espacio cibernético es tan flagrante como el delirio de los niños perfectos, fabricados por la medicina y entregados con sello de cualidad morfológica y genética. El sexo fue substituido por el texto, por múltiples grafismos que buscan transmitir la emoción y el gozo en un erotismo de suprema higiene que elimina el cuerpo físico en provecho del virtual. Pero el cuerpo es testarudo y permanece ¡Que odio! Entonces comienza la guerra por perfeccionar lo imperfecto y vienen tatuajes, piercings, body-modificatios, anabolizantes, transexualismos, bodybuilding, body-art... como si mudar el cuerpo fuese suficiente para mudar la vida (LE BRETON, 2013). Pero nada de eso basta. Y es que no quisimos escuchar a San Agustín; atacamos al cuerpo, pero es el alma presa la que se manifiesta en síntomas y enfermedades. Así, en el lugar de la recapacitación hay medicalización, manipulación de sí, fármacos para dormir, despertar, estar en forma, tener energía, memoria, vencer la ansiedad, el estrés (LE BRETON, 2013: p.22), en fin, una a una se amontonan las prótesis químicas hasta alcanzar el punto de la fuga, la asimilación de la ruptura en la que la instrumentación psicotrópica mantendrá a flote una pseudoexistencia, un resto a la deriva entre ser y huir de sí. 


\section{La astucia} acompañar la peregrinación mística de los huicholes de México en busca del peyote. El peyote es un cactus con propiedades psicotrópicas, por lo que, a un momento dado, el antropólogo se pregunta sobre el consumo de drogas en las civilizaciones contemporáneas. Desde nuestra perspectiva - sin arte y sin religión - podríamos abrigar esperanzas de que, al menos, mantendríamos el rito como posibilidad de reencuentro con El Dorado perdido; de hecho, tatuajes, piercings, body-modifications o el uso de substancias psicoactivas, vigentes en nuestro tiempo, han sido constantes en celebraciones rituales de numerosas culturas por todo el planeta. No obstante, la observación sensible de Benitez, sin mucho esfuerzo, diluye esa expectativa, argumentando que, carentes de una "expectativa de salvación", es decir, de noción de transcendencia, los actuales adeptos a las drogas limitarían su experiencia a una fuga hacia dentro de sí; diferente de los huicholes que conducirían el efecto psicotrópico al goce de una participación cósmica ${ }^{3}$.

que la tentativa de deshacernos de los dioses es un tentativa de amputar una parte de nosotros mismos y que de la parte amenazada surgen malestares e enfermedades que nos asolan (SALIS, 2017: p.12). En atención a mis propósitos y competencias, entretanto, dejaré de lado los registros pandémicos de la angustia, la depresión y el suicidio ${ }^{2}$ para focalizar, como lo he señalado, en el problema mundial de la dependencia química que, según la Organización Mundial de la Salud, es responsable por nada menos que 450,000 muertes por año ${ }^{3}$.

Es altamente significativo que los narcóticos se hallan tornado un problema apenas recientemente. Según Duarte, solo a mediados del siglo XIX la idea de que el opio, por ejemplo, no tenía efectos nocivos comenzó a disiparse (2005: p.138). Entre los siglos IX e XIX de nuestra era, el opio y sus derivados gozaban de gran prestigio en la medicina. En China, durante casi mil años, la substancia fue usada en el tratamiento de diarrea y en la era Victoriana fue un apreciado soporte terapéutico (DUARTE, 2005: p.137). En la antigüedad, abundan los registros del uso ritual de narcóticos entre los egipcios, griegos y judíos (DUARTE, 2005); en Asia central y en Siberia (ELIADE, 1964); así como en América, por supuesto (GONZÁLES TORRES, 2001)(LABATE; ARAÚJO, 2002).

Ilustro otro dato interesante en una muestra constituida por tres casos: Primero, la denuncia de Ciro Guerra en su citada película, El Abrazo de la Serpiente, de que el restante del pueblo cohiuano, después de violentado por los temidos Barones del caucho, se tornó dependiente químico de la ficticia Yakruna ${ }^{4}$, planta de propiedades narcóticas que, en la vigencia de la cultura mágica cohiuana, había sido el centro de su complejo ritual (GUERRA, 2015). Esto se confirma en el trabajo de Leila Tardivo, resultante de su visita al pueblo tukano del Alto Rio Negro, en Amazonas, donde observó que como parte del proceso de aculturación de esa etnia a los moldes occidentalizados de la federación brasileña - a despecho de sus mitos, rituales y costumbres - se desencadenó una creciente onda depresiva, violenta y suicida que gira entorno de la dependencia química (TARDIVO, 2007). En tercer lugar, traigo a la memoria el trágico pasaje histórico de las llamadas Guerras de Opio. Como mencioné, los chinos consumían opio había muchos siglos; sin embargo, ese consumo solo se tornó problemático a partir del siglo XVIII con los inescrupulosos incentivos portugueses, franceses e ingleses, interesados en la expansión de sus mercados (DUARTE, 2005). 
Estos datos sugieren que la dependencia química es un fenómeno que sobreviene con la posesión del chulachaqui, es decir, es un riesgo que acompaña la disociación neurótica que caractericé inicialmente. Hipótesis que se ve respaldada por los datos publicados por la OMS, los cuales confirman que las mayores incidencias en el consumo adictivo de drogas lícitas e ilícitas se encuentran en Canadá, Estados Unidos y Europa occidental (OMS, 2004). En otras palabras, el problema de la dependencia química se concentra con mayor fuerza en los países desarrollados; recordando que ese desarrollo se mide principalmente en términos económicos, lo que, según Bauman y May (2010), en perspectiva capitalista, guarda una estrecha relación con la capacidad que esos países tienen de apropiarse, por múltiples medios, de los recursos materiales y humanos de sus congéneres. Si reducimos esta imagen al continente americano, obtendremos que América - la parte sin latín - es la consciencia continental que, centrada en su Ego, tiene la convicción de que puede disponer de todo, pues todo le pertenece. Bueno, pues ese espíritu escindido, ególatra, tiene un serio problema de dependencia química. Del otro lado, está el sucio y desparpajado demonio latinoamericano. La parte no desarrollada, la de los bajos instintos de pura sobrevivencia, la que, al intuir problemas prefiere sus santos, su virgen morena, sus muertos, fiestas, salsa, cumbia y samba antes que cualquier esfuerzo de reflexión. América latina es el alma presa en el cuerpo, el alma oprimida por la retirada constante de sus recursos y posibilidades. Paradójicamente, esta es la parte que produce y distribuye la droga que sustenta el vicio de la parte desarrollada. ¿Qué hacer? No lo sé. Yo acudiría a la vieja fórmula: ¿Y ahora, quién podrá defendernos? Aunque la atención al llamado, evidentemente, no sería la misma para las dos partes:

En la parte VIP (Very Important Person), la parte ególatra de los opuestos, el llamado, para tener algún sentido, tendría que ser dirigido a un ser superior; solo que, I'm sorry, ¡No hay ser superior! Es un espíritu escindido justamente porque amputó sus dioses, algo así como el famoso: Dios está muerto, que alguna vez ocurrió a Nietzsche. Como explica Jung, el llamado a un ser superior, a falta de correspondencia externa, retorna al sujeto, haciéndolo creer que alcanzó las características del ser que convocaba y constituyendo una prepotente y destructiva Semejanza con Dios (JUNG, 1990: p.35). Vale destacar el testimonio de James A. Hall, quien narra que, actuando como psiquiatra del ejército norteamericano, escuchó de varios pacientes usuarios de LSD la convicción de que su inadaptación se debía a la incomprensión, por parte de los demás, de que Dios era su verdadera identidad (HALL, 1995: p. 55). Así, quien acude al llamado norteamericano es el Capitán América, un siempre joven casto y abnegado, sacrificado y resucitado, actuante por encima de la ley, dada su invulnerabilidad moral, detentor de poderes tecnológicos súper-avanzados; a pesar de único e inalcanzable, pues la tecnología que lo hizo murió con su creador. Capitán América viste los colores y las estrellas de la nación, pues es la imagen resultante del proceso psíquico de la semejanza con dios. En el plano práctico, por lo tanto, no debemos esperar grandes transformaciones por parte del superhéroe. Como flota encima de la ley, no se cuestiona y su invulnerabilidad moral, oriunda de aquella inmovilidad moral que referí, se empeña en mantener todo como está. Dicho de otra forma, un ser perfecto, incuestionable e inalcanzable, no se interesa por cualquier tipo de transformación. continental, retumba la respuesta: ¡Yo, el Chapulín Colorado! 
Capitán América no es un héroe, el prefijo super denuncia una manipulación artificiosa de sus cualidades arquetípicas (SOARES; VELÁZQUEZ, 2017). Como dijo Jacobi, un arquetipo, a pesar de tender al mundo de las imágenes e ideas, del otro lado se sujeta en los procesos biológicos de la naturaleza (JACOBI, 1995: p.43). La dinámica natural es la transformación y eso es un principio que el superhéroe rechaza. El Chapulín Colorado, al contrario, es un héroe típico del primer ciclo. Un héroe tramposo, estafador, el héroe trickster; el que con su estupidez consigue lo que otros, más hábiles y mejor instrumentados, no consiguen. Talvez la estupidez sea su mayor cualidad, pues supone inocencia e inconsecuencia, lo que lo libera para actuar impulsado apenas por el ímpetu de la transformación. Como "reflejo fiel de una consciencia humana indiferenciada en todos los aspectos, correspondiente a una psique que, por decirlo de alguna manera, aún no ha dejado el nivel animal" (JUNG, 2014: p.262), sin saberlo ni pretenderlo, su trayectoria se orienta a la conquista de los ciclos heroicos siguientes. En este sentido, el Chapulín revela su faz demoniaca, pues se presenta como energía disponible para hacer frente a una adversidad (VELÁZQUEZ, 2017: pp.63-64). Demonio deriva del griego daímōn, que significa divinidad, destino, una fuerza o potestad que ejerce algo (BRANDÃO, 2014: p. 168). En pocas palabras, el Capitán América es perfecto y, por lo tanto, estático, pues nada precisa conquistar; el Chapulín Colorado, en cambio, es tan primario e imperfecto que tiene toda la saga heroica, es decir, toda la potencialidad de crecimiento e perfeccionamiento por realizar.

26 En términos psíquicos, la aparición de este nuevo demonio se configura como un complejo autónomo. De acuerdo con Jung, ante una adversidad para la cual la consciencia no tiene respuesta, la energía psíquica (libido) disminuye en funciones conscientes para correr en sentido contrario (enantiodromia), hacia el inconsciente, donde activa alguna región, hasta entonces pasiva, que tenderá a desarrollarse con la asimilación de materiales afines, en vista de formular una respuesta creativa (JUNG, 1971: p. 68). Esta nueva constelación de materiales inconscientes es autónoma porque no es comandada por la consciencia - al menos no completamente - al tiempo en que la región inconsciente que constela las nuevas potencialidades era ajena al problema, estaba inactiva.

Sobre lo expuesto, podemos revisitar un poco de historia. Como mencioné, Portugal, Francia y, sobretodo, Inglaterra, incrementaron de forma inescrupulosa el consumo adictivo del opio en China. Pues sucede que, más tarde, a finales del siglo XIX, parte de los chinos adictos fue llevada a México para trabajar en la construcción de líneas férreas y en la explotación de minas. Como afirma Valdés Castellanos, los chinos"[...] trajeron las semillas de amapola y el conocimiento para cultivarlas y transformarlas en opio" (2013: p. 3), lo que incentivó pequeños grupos adictos en los círculos sociales adinerados $\mathrm{y}$, en consecuencia, una rudimentaria e inexpresiva red, legal durante un tiempo, de producción y distribución de opio en México.

El siglo XX transcurrió lleno de significativos conflictos armados y, como dice Saviano, "sin morfina no se hace una guerra, porque la guerra es dolor de huesos quebrados y carnes laceradas [y] [...] para la carne que quema sólo hay una cosa: la morfina." (2013: pp.24-25) Así, América necesitó morfina para la guerra, pero, siendo ya ilícita en la época, su inmovilidad moral impidió su producción local. Parte de la atención angloamericana se volvió, por lo tanto, para su vecino del sur. En México, liminar del inconsciente continental, podrían, lejos de la vista, desarrollarse los procesos necesarios que no se quiere reconocer en el inmaculado territorio de la consciencia. Entonces, secretamente, 
América solicitó a México la producción del opio que necesitaba y hasta construyó trechos de ferrovías para agilizar su transporte (SAVIANO, 2013: p.26).

Recapitulemos: ante la consciencia americana se presentó una adversidad, la guerra, para la cual no se tenía experiencia ni preparo. Esta buscó entonces reunir elementos de los que no disponía y, consecuentemente, parte de su atención, de la energía empleada en el problema, corrió en sentido contrario, hacia América Latina, el inconsciente continental, donde activó una región que hasta ese momento era insignificante. ¡No contaban con mi astucia! El núcleo que originó la enorme red de crimen organizado que hoy ampliamente transborda la América Latina sigue los estándares de un complejo autónomo.

Recordemos que el complejo autónomo se desarrolla en vista de formular respuestas creativas. Por eso, ante la vasta necesidad de opio para la guerra, la creatividad latinoamericana reunió lo necesario para responder a la demanda. Pero la cuestión es que el fin de la guerra no hizo cesar la demanda, como observa Valdés Castellanos, "la razón de ser de los narcotraficantes mexicanos ha sido el mercado estadounidense" (2013: p.22), un mercado que, lejos de minguar, hoy alcanza los países del primer mundo en los cinco continentes. Naturalmente, una demanda de tal porte favorece el continuo crecimiento del tejido narcotraficante, al punto de confundirse actualmente con las instituciones políticas de los territorios que ocupa (VALDÉS CASTELLANOS, 2013). Su progresión, no obstante, es claramente orgánica pues, a pesar de ser comparable a grandes empresas transnacionales, no es oriunda de la lógica empresarial; antes se encuadra en la lógica criminalística de las redes, estructuras que se auto organizan "[...] a partir de la conducta que van adquiriendo las partes que la componen." (VALDÉS CASTELLANOS, 2013: pp.36-37) Y es, de hecho, en la conducta donde se justifica la fusión de los carteles de drogas con las instituciones de estado, ya que no es raro que se constituyan como verdaderos estados paralelos. Una evidente consecuencia de la omisión irresponsable y corrupta de instituciones y de agentes institucionales que, en América Latina, marginalizan importantes parcelas connacionales en favor propio, de sus elites y de sus articulaciones transnacionales. Tomo como ejemplo el caso del cártel La Familia, que estuvo en auge en el estado mexicano de Michoacán, en torno del año de 2006. Esta organización, además de financiar proyectos comunitarios en materia de educación, salud, urbanismo y espiritualidad, también controlaba la microcriminalidad en su región. En su código moral, estableció claramente que las drogas que producía eran destinadas al consumo extranjero y, bajo ninguna circunstancia, al consumo local. Los jóvenes adictos de la región fueron incentivados y financiados para su desintoxicación y acogidos con garantías sociales y empleos en las redes criminales. En contrapartida, los reincidentes fueron asesinados (SAVIANO, 2013: pp.79-82). En este contexto, no parece extraño que una parcela significativa de la población joven de Latinoamérica considere como perspectiva viable - y a veces única - su incursión en el crimen organizado (SOUS GONZÁLES, 2013: p.27). A pesar de invisible a ojos lícitos, las redes latinoamericanas de narcotráfico constituyen hoy una potente cultura emergente.

\section{Consideraciones soteriológicas}

31 Parecería que estamos ante el espectáculo de una lucha entre la licitud consciente y la metástasis imparable del crimen organizado; pero no es así. El Capitán América cree que todo está perfecto y por eso es guardián del orden establecido. En sus delirios 
financieros estima la dependencia química no como un problema, sino como una importante fuente de rendimientos. El oleaje nauseabundo del lavado de dinero y del tráfico de armas, esencial al narcotráfico, también es de grande estima en la preservación saludable de sus acciones capitales. Como dije inicialmente, es un chulachaqui vagando a la deriva sobre las aguas razas de la riqueza especulativa.

Por su lado, el Chapulín Colorado crece. Para eso surgió. Y en la medida que crece, madura ¿Quién sabe si las paulatinas legalizaciones de estupefacientes que surgen por el continente no son los primeros brotes de un complejo que transborda? Infelizmente no hay un enfrentamiento. $Y$ digo infelizmente porque un combate, por detrás de su nube de violencia, podría descubrir una articulación entre combatientes o el apaciguamiento de una de sus partes; pero, en vez de eso, cada un procede ensimismado en su tendencia.

No se puede, por eso, pensar este cuadro como una lucha entre el bien y el mal. Bien y mal son apenas perspectivas y ambas existen en número equivalente en los dos puntos de vista. Lo que se puede constatar es que, en cuanto haya demanda, el complejo de los narcóticos continuará constelando materiales y ofreciendo respuestas. Observamos más bien el surgimiento de un nuevo nicho cultural, talvez del porte del cristianismo que subvirtió la Roma del pan y circo e inauguró la Edad Media; o de la clase burguesa que desbancó los cánones nobles y dio lugar a la era moderna e, insisto, no es posible afirmar que en esos procesos alguna de las partes, o el proceso en sí, fue absolutamente bueno o malo.

En todo caso, se trata de un proceso inconsciente, en buena parte, porque nos negamos a reconocerlo. Sabemos que la simple represión no lo resuelve; semejante a un proceso clínico-analítico, habrá que reconocerlo, comprenderlo y negociar con él, a fin de asimilarlo.

¿Cómo hacerlo? No lo sé. Ni siquiera sé si aún es tiempo. Lo que sé es que nada se oculta para siempre, represas transbordan y cuando materiales hartos y potentes derraman sobre la pulcritud de la consciencia provocan ataques psicóticos. ¡Síganme los buenos!

\section{BIBLIOGRAFÍA}

Resultados parciales de esta investigación fueron presentados en el Congreso Regional de la Sociedad Internacional de Musicología "Music as Art, Artefact and Fact. Music Research in the 21st Century", Stavanger, 05.07.2016; y en el Primer Coloquio Internacional Violeta Parra, Santiago de Chile, 30.08.2017. Este artículo se nutre de valiosas discusiones surgidas con colegas en ambas instancias.

ARGUEDAS, J. M.; RÍOS, F. I. Mitos, leyendas y cuentos peruanos. Lima: Siruela, 2009.

BARRAL I ALTET, X. História da arte. Campinas, SP: Papirus, 1990.

BAUMAN, Z.; MAY, T. Capitalismo parasitário: e outros temas contemporâneos. Rio de Janeiro: Zahar, 2010. 
BENÍTEZ, F. En la tierra mágica del peyote. México: Era/Lom/Trilce/Txalaparta, 2010.

BRANDÃO, J. DE S. Dicionário mítico-etimológico da mitologia grega. Petrópolis, RJ: Vozes, 2014.

CAMPBELL, J. Mito e transformação. São Paulo: Ágora, 2008.

CANCLINI, N. G. A Sociedade sem Relato: Antropologia e Estética da Iminência. São Paulo: EDUSP, 2012.

CANCLINI, N. G. La expansión de la cultura: Incomodidades para las ciudades y el arte. In:

CANCLINI, N. G.; VILLORO, J. (Org.). . La creatividad redistribuída. $1^{\text {a }}$ ed. México: Siglo XXI editores / Centro Cultural de españa en México, 2013. p. 9-83.

CHARBONNIER, G. Arte, linguagem, etnologia - Entrevistas com Claude Lévi-Strauss. Campinas, SP: Papirus, 1989.

DANTO, A. El fin del arte. Adamar, p. 1-19, 2000. Disponível em: <http://adamar.org/ivepoca/ node/888>.

DANTO, A. O mundo da arte. Artefilosofia, p. 13-25, 2006. Disponível em: <https://bit.ly/2MySpVi>.

DUARTE, D. F. Uma Breve História do Ópio e dos Opióides. Revista Brasileira de Anestesiologia, v. 55, n. № 1, Janeiro-Fevereiro, p. 135-146, 2005.

ELIADE, M. Mito do eterno retorno. São Paulo: Mercuryo, 1992.

ELIADE, M. Mito e realidade. São Paulo: Perspectiva, 1972.

ELIADE, M. 0 sagrado e o profano. $5^{\text {a }}$ tir. ed. São Paulo: Martins Fontes, 2001.

ELIADE, M. Shamanism. Digital ed. London: Princeton University Press, 1964.

FRANCASTEL, P. Pintura e sociedade. $1^{\text {a }}$ ed. ed. São Paulo: Martins Fontes, 1990.

GOMBRICH, E. H. A história da arte. 16ª ed. ed. Rio de Janeiro: LTC, 2008.

GÓMEZ DE SILVA, G. Breve diccionário etimológico de la lengua española. 2ª ed. México: FCE, 1998.

GONZÁLES TORRES, Y. (Org.). Animales y plantas en la cosmovisión mesoamericana. México: Plaza y Valdés, 2001.

GREEMBERG, C. Vanguarda e Kitsch. In: FERREIRA, G.; MELLO, C. C. DE (Org.). . Clement Gremberg e o debate crítico. Rio de Janeiro: Funarte Jorge Zahar, 1997. v. 9. p. 27-43.

GUERRA, C. El abrazo de la serpiente. . Colombia: Oscilloscope Pictures / Diaphana Films. , 2015

GUILBAUT, S. De cómo Nueva York robó la idea de arte moderno. Valencia: Tirant Lo Blanch, 2007.

GUTIÉRREZ, L. M.; TORRES, M. A. Así soñaron los antiguos. Bogotá: Viento, 2016.

HALL, J. A. A experiência junguiana - análise e individuação. 10ª ed. São Paulo: Cultrix, 1995.

JACOBI, J. Complexo, Arquétipo, Símbolo na psicologia de Jung. 10ª ed. São Paulo: Cultrix, 1995.

JUNG, C. G. A natureza da psique. 10ª ed. ed. Petrópolis: Vozes, 2013.

JUNG, C. G. Aspectos do drama contemporâneo. $2^{\text {a }}$ Ed. ed. Petrópolis: Vozes, 1990.

JUNG, C. G. O espírito na Arte e na Ciência. Petrópolis, RJ: Vozes, 1971.

JUNG, C. G. O homem e seus símbolos. $6^{\text {a }}$ ed. ed. Rio de Janeiro: Nova Fronteira, 1964.

JUNG, C. G. Os arquétipos e o inconsciente coletivo. 11 a ed. Rio de Janeiro: Vozes, 2014.

JUNG, C. G. Psicologia e alquimia. 5a ed. ed. Petrópolis, RJ: Vozes, 2011.

JUNG, C. G. Tipos psicológicos. $3^{\text {a }}$ ed. ed. Petrópolis, RJ: Vozes, 2009. 
KURY, M. DA G. Dicionário de mitologia grega e romana. $8^{\text {a }}$ ed. v. ed. Rio de Janeiro: Zahar, 2009.

LABATE, B. C.; ARAÚJO, W. S. (Org.). O uso ritual da ayahuasca. Campinas, SP: FAPESP/Mercado das Letras, 2002.

LE BRETON, D. Adeus ao corpo: Antropologia e sociedade. Campinas, SP: Papirus, 2013.

LE CLÉZIO, J. M. G. Le rêve mexicain. La Flèche, France: Gallimard, 1988.

LE GOFF, J. Para uma outra Idade Média - Tempo, trabalho e cultura no ocidente. Petrópolis, RJ: Vozes, 2013.

LEÓN-PORTILLA, M. La filosofia Náhuatl estudiada en sus fuentes. $9^{\text {a }}$ ed. México: UNAM, 2001.

LÉVI-STRAUSS, C. O cru e o cozido. $2^{\text {a }}$ ed. São Paulo: Cosac Naify, 2010.

LÉVY-BRUHL, L. La mentalité primitive - Chapitres 1 à 7. électroniq ed. Chicoutimi, Québec: Bibliothèque Paul-Émile-Boulet de l'Université du Québec à Chicoutimi, 2002.

MICHAUD, Y. El arte en estado goseoso - Ensayo sobre el triunfo de la estética. $1^{\text {a }}$ ed. en ed. México: FCE, 2007.

MORIN, E.; CIURANA, E.-R.; MOTTA, R. D. Educar na era planetária - O pensamento complexo como método de aprendizagem pelo erro e incerteza humana. São Paulo: Cortez, 2003.

MUSEU DE IMAGENS DO INCONSCIENTE (Org.). Exposição: Os inumeráveis estados do ser. Rio de Janeiro: Sociedade Amigos do Museu de Imagens do inconsciente, 1987.

OMS. Neurociências: consumo e dependência de substâncias psicoativas: resumo. . Genebra: [s.n.], 2004.

PENNA, E. M. D. O paradigma junguiano no contexto da metodologia qualitativa de pesquisa. Psicologia USP, v. 16, n. C, p. 71-94, 2004.

PLATÃO. A República (E. Corvisieri trad.). São Paulo: Nova Cultural, 2000.

PLATÃo. Timeu e Crítias ou a Atlântida. Curitiba, PR: Hemus, 2002.

PLOTINO. Ennéades. Tome IV. Paris: Les Belles Lettres, 2012.

SALIS, V. D. Prefácio: Mito, olhar e magia. In: VELÁZQUEZ, C. (Org.). . Pensar no MITHO. $1^{\mathrm{a}} \mathrm{ed}$. Jundiaí, SP: Paco, 2017. p. 11-16.

SAN AGUSTÍN. Sobre la música. Madrid: Editorial Gredos, 2008.

SAVIANO, R. Zero zer zero. e-pub ed. São Paulo: Companhia das letras / Editora Schwarcz, 2013.

SOARES, A.; VELÁZQUEZ, C. Eu, meu herói - Entre o Mito e o Super. $1^{\text {a }}$ ed. ed. Joinville, SC: Unifor / Clube de autores, 2017.

SOUS GONZÁLES, J. L. Neoliberalismo y crimen organizado en México: El surgimiento del Estado narco. Frontera norte, v. 25, n. 50, p. 7-34, 2013.

SUBIRACHS, J. M. Um buraco no espaço. História Geral da Arte - Escultura I. Madrid: Ediciones del Prado, 1995. p. 9-12.

TARDIVO, L. S. DE L. P. C. Sofrimento, desenraizamento e exclusão: relato de uma experiência com indígenas aculturados do Amazonas. Psicologo informação, v. 11, n. 11, p. 113-126, 2007.

VALDÉS CASTELLANOS, G. História del narcotráfico en México. EPUB ed. México: Santillana, 2013.

VELÁZQUEZ, C. Mas afinal, o que é estética? Por uma redescoberta da educação sensível. Lisboa: Chiado Editora, 2015.

VELÁZQUEZ, C. Mitologias para o século XXI - Facultas Characteristica. Jundiaí, SP: Paco, 2017. 


\section{NOTAS}

1. Como dice Le Goff, "triunfa el retrato, que ya no es la imagen abstracta de un personaje representado por símbolos, signos que materializan el lugar y la categoría que Dios les asignó, sino otra que presenta al individuo capturado por el tiempo, en el concreto espacial y temporal, no en su esencia eterna, sino en su ser efímero, que exactamente el arte, en su nueva función, tiene por objeto inmortalizar." (2013: p. 73)

2. Nada existe realmente que pueda ser llamado Arte. Solamente existen artistas. [...] No perjudica a nadie darle el nombre de arte a todas esas actividades, desde que se conserve en mente que tal palabra puede significar cosas muy diversas, en tempos e lugares diferentes, y que el Arte con A mayúscula no existe. La verdad, Arte con A mayúscula pasó a ser algo como el coco, como un fetiche. Podemos aplastar un artista diciéndole que lo que acaba de hacer puede ser excelente a su modo, solo que no es "Arte". Y podemos desconcertar cualquier persona que esté contemplando con deleite un cuadro, declarando que lo que tanto aprecia no es Arte sino algo muy diferente. (GOMBRICH, 2008: p.15)

3. [...] los adeptos de la LSD, a diferencia de los huicholes, carecen de una 'expectativa de salvación'. [...] El cliente de la LSD, de acuerdo con la propaganda turística, hará un viaje al centro de su cerebro. Traspasadas las barreras defensivas de su coherencia, alterado su funcionamiento mental, asistirá indefenso a la dispersión y fragmentación de su yo, no tendrá antídotos contra el miedo, y el vislumbre de sus pequeños infiernos, de la inutilidad de su vida, lo sumirá con frecuencia en un estado depresivo que no compensará el deleite momentáneo que pueda proporcionarle la droga. El viaje para los huicholes, en cambio, está sujeto a un itinerario fijo: son los dioses los que lo han trazado a lo largo de las serranías y de los desiertos. En cada una de sus jornadas ha ocurrido un hecho relacionado con hazañas sobrenaturales. [...] Dentro de ese proceso de sacralización, no figuran las reacciones personales. La psicología apenas juega un papel, lo que cuenta no es la individualidad sino las ideas colectivas. (BENÍTEZ, 2010: pp.97-98)

\section{NOTAS FINALES}

1. La etnia cohiuana, como su sabio Karamakate, son ficciones cinematográficas alusivas a grandes trazos de la organización y pensamiento mágicos, comunes a diversos pueblos de la selva amazónica.

2. OPAS / OMS en https://goo.gl/pQdzZ4 Accedido en 31 de junio de 2018.

3. OMS em https://goo.gl/8FZnfj Accedido en 31 de junio de 2018.

4. Probablemente la chacrona, planta usada en la preparación del té del Santo Daime, según Viveros de Castro. https://bit.ly/2CXsmaX, Accedido en 2 de agosto de 2018

\section{RESÚMENES}

Mediante la comparación de la historia constitutiva del continente americano con un proceso disociativo de la consciencia, con recurso a los preceptos de la investigación cualitativa de paradigma junguiano (PENNA, 2004), metaforizo el continente con las cualidades psíquicas de la dicotomía consciencia / inconsciente, a fin de, en reducción, observar el fenómeno del surgimiento y desarrollo del narcotráfico. Imágenes de cuño mitológico surgen en el proceso y ofrecen indicios al ejercicio interpretativo. Concluyo con la sugestión del surgimiento de un nuevo nicho cultural, capaz de impulsar significativos cambios en el orden social contemporáneo. 
Guidé par les préceptes de la recherche qualitative sur le paradigme jungien (PENNA, 2004), je procède à métaphoriser le continent en le donnant des qualités psychiques à partir de la dichotomie conscience / inconscience, afin d'observer le phénomène de l'émergence et du développement du trafic de drogues. Certaines images ayant l'air mythologiques, émergent dans le processus, offrant des pistes à l'exercice d'interprétation. Je conclus par la suggestion d'un nouveau domaine culturel, capable de promouvoir de changements importants dans l'ordre social contemporain.

\section{ÍNDICE}

Mots-clés: Héros; Trickster; Démon ; Complexe autonome ; Trafic de drogues.

Palabras claves: Héroe; Trickster; Demonio; Complejo autónomo; Narcotráfico.

\section{AUTOR}

\section{CARLOS VELÁZQUEZ}

Profesor titular de la Universidade de Fortaleza - Unifor, Brasil / Colaborador del CLLC de la Universidade de Aveiro, Portugal.

caveru@unifor.br 